\title{
PPARGC1B Gene
}

National Cancer Institute

\section{Source}

National Cancer Institute. PPARGC1B Gene. NCI Thesaurus. Code C101766.

This gene is involved in the positive regulation of transcription. 